\title{
ANALISIS SISTEM PELEPASAN INFORMASI REKAM MEDIS DALAM MENJAMIN ASPEK HUKUM KERAHASIAAN REKAM MEDIS DI RUMAH SAKIT IMELDA PEKERJA INDONESIA MEDAN TAHUN 2018
}

\author{
${ }^{1 .}$ Erlindai; ${ }^{2 .}$ Tania Yulita \\ ${ }^{1 .}$ Dosen APIKES Imelda, Jalan Bilal Nomor 52 Medan; ${ }^{2 .}$ Alumni APIKES Imelda \\ E-mail: ${ }^{1 .}$ erlindaipurba@gmail.com
}

\begin{abstract}
ABSTRAK
Sarana pelayanan kesehatan bertanggung jawab untuk melindungi informasi kesehatan yang terdapat di dalam rekam medis terhadap kemungkinan hilang, rusak, pemalsuan dan akses yang tidak sah. Secara keseluruhan, keamanan (security), privasi (privacy), kerahasiaan (confidentiality) dan keselamatan (safety) adalah perangkat yang membentengi informasi dalam rekam medis. Jenis penelitian ini adalah deskriptif kualitatif. Sampel dalam penelitian ini yaitu Direktur Rumah Sakit, Kepala Rekam Medis Rumah Sakit dan Petugas Penyimpanan Rumah Sakit. Analisis data yang digunakan adalah distribusi frekuensi dan juga narasi dari hasil wawancara yang dilakukan. Dan dari hasil penelitian yang dilakukan di RSU Imelda Pekerja Indonesia Medan sudah optimal dan sudah melaksanakan SOP. Bagi instansi rumah sakit agar dalam menjaga kerahasiaan dan keamanan informasi pasien di RSU Imelda Pekerja Indonesia Medan, sebaiknya untuk pencatatan peminjaman atau untuk melakukan pelepasan informasi untuk pihak ke-3 dalam mendokumentasikan sebaiknya rumah sakit imelda medan menggunakan pendokumentasian terkomputerisasi agar lebih aman dan mudah untuk perhitungan data, pendokumentasian bertujuan sebagai bentuk bukti apabila terjadi tuntutan kelak.
\end{abstract}

Kata Kunci: Analisis, Sistem Pelepasan Informasi Rekam Medis, Hukum Kerahasiaan Rekam Medis, Rumah Sakit.

\section{PENDAHULUAN}

Rumah sakit adalah bagian integral dari suatu organisasi sosial dan kesehatan dengan menyediakan pelayanan paripurna (komprehensif), penyembuhan penyakit (kuratif), dan pencegahan penyakit (preventif) kepada masyarakat (WHO, 2000). Rumah sakit merupakan salah satu fasilitas pelayanan kesehatan yang memiliki peran penting dalam upaya mempercepat peningkatan derajat kesehatan masyarakat. Menurut Undang-Undang Republik Indonesia Nomor 44 tahun (2009) tentang rumah sakit bahwa rumah sakit mempunyai kewajiban pelayanan kesehatan yang aman, bermutu, anti diskriminasi dan efektif dengan mengutamakan kepentingan pasien sesuai standar pelayanan rumah sakit.

Kompleksitas ini muncul karena pelayanan rumah sakit menyangkut berbagai fungsi pelayanan, pendidikan, dan penelitian, serta mencakup berbagai tingkatan maupun jenis disiplin, dimana rumah sakit mampu melakasanakan fungsi yang profesional baik dibidang teknis medis maupun administrasi kesehatan (Rustiyanto, 2009).

Berdasarkan Permenkes (2008), Rekam Medis adalah berkas yang berisi catatan dan dokumen antara lain identitas pasien, hasil pemeriksaan, pengobatan yang telah diberikan, serta tindakan dan pelayanan lain yang diberikan kepada pasien. Catatan merupakan tulisan-tulisan 
yang dibuat oleh dokter atau dokter gigi mengenai tindakan-tindakan yang dilakukan kepada pasien dalam rangka pelayanan kesehatan.

Salah satu penilaian dari pelayanan kesehatan dapat kita lihat dari pencatatan rekam medis atau rekam kesehatan. Dari pencatatan rekam medis dapat menggambarkan kualitas pelayanan kesehatan yang diberikan pada pasien, serta meyumbangkan hal penting dibidang hukum kesehatan, pendidikan, penelitian dan Akreditasi Rumah Sakit (Tahalal dan Hiswani, 2009).

Sarana kesehatan bertanggung jawab un tuk melindungi informasi kesehatan yang terdapat di dalam rekam medis terhadap kemungkinan hilang, rusak, pemalsuan dan akses yang tidak sah. Menjaga keamanan informasi, keakuratan informasi dan kemudahan akses informasi menjadi tuntunan pihak organisasi pelayanan kesehatan dan praktisi kesehatan serta pihak ke-3 yang berwewenang. Sedangkan pihak yang membutuhkan informasi harus senantiasa menghormati privasi pasien. Secara keseluruhan, keamanan (security), privasi (privacy), kerahasian (confidentiality) dan keselamatan (safety) adalah perangkat yang membentengi informasi dalam rekam medis.

$$
\text { Indonesia memiliki peraturan }
$$

perundang-undangan yang mengatur penyelenggaraan rekam medis dimuat di dalam Undang-Undang No. 23 tahun 1992 Kesehatan, Undang-Undang No 29 tahun 2014 tentang Praktek Kedokteran, dan Permenkes (2008). Selain itu juga terdapat ketentuan perundang-undangan di bidang wajib simpan rahasia kedokteran yang berhubungan dengan penyelenggaraan Manajemen Informasi Kesehatan (MIK), seperti pasal KUHP rahasia jabatan/pekerjaan, PP No. 10 tahun 1966 tentang Wajib simpan rahasia Kedokteran, dan kedua Undang-Undang di atas (Firdaus S, 2008).

Rekam medis harus menyajikan informasi yang akurat dan lengkap tentang proses pelayanan medis dan kesehatan di rumah sakit, baik masa lalu, masa kini maupun yang diperkirakan akan terjadi dimasa mendatang (Muninjaya AAG, 2016).

Berdasarkan uraian di atas prosedur pelepasan informasi rekam medis harus disertai dengan ijin tertulis dari pasien selaku pemilik informasi dalam rekam medis, begitu pula dengan pemaparan isi rekam medis haruslah dokter yang merawat pasien tersebut.

Melihat pentingnya Kerahasian, Privasi dan Keamanan berkas rekam medis dalam meningkatkan mutu pelayanan dan pelepasan informasi di rumah sakit maka peneliti tertarik untuk melakukan penelitian dengan judul "Analisis Sistem Pelepasan Informasi Rekam Medis Dalam Menjamin Aspek Hukum Kerahasiaan Rekam Medis di Rumah Sakit Umum Imelda Pekerja Indonesia Medan".

\section{Rumusan Masalah}

Berdasarkan latar belakang di atas, maka peneliti merumuskan masalah penelitian yaitu "Analisis Sistem Pelepasan Informasi Rekam Medis Dalam Menjamin Aspek Hukum Kerahasian Rekam Medis di Rumah Sakit Imelda Pekerja Indonesia Medan"

\section{Tujuan Penelitian}

Adapun yang menjadi tujuan dalam penelitian ini adalah untuk Meninjau pelepasan informasi Rekam Medis Tentang Penerapan Standar Kerahasian, Privasi dan Keamanan Informasi Tentang Dokumen Rekam Medis di Rumah Sakit Imelda Pekerja Indonesia Medan.

\section{Manfaat Penelitian}

1. Bagi Rumah Sakit

Dapat dijadikan bahan kritikan dan masukan serta bahan tambahan dalam meningkatkan aspek hukum kerahasian rekam medis pasien.

2. Bagi Insitusi Pendidikan

Sebagai bahan perbandingan atau referensi pada studi atau penelitian di masa yang akan datang.

3. Bagi Peneliti

Sebagai pengalaman, Khususnya dalam melakukan penelitian ilmiah sekaligus 
menambah pemahaman dan pengetahuan tentang ilmu rekam medis

4. Bagi Mahasiswa Apikes Imelda Medan dapat dijadikan sebagai pedoman dan bahan bacaan di perpustakaan Imelda Medan dan sebagai bahan perbandingan maupun acuan bagi peneliti selanjutnya.

\section{METODE}

\section{Metode Penelitian}

Metode yang digunakan dalam penelitian ini adalah penelitian deskriptif kualitatif, pendekatan penelitiannya menggunakan cross sectional, metode penelitiannya menggunakan observasi dan wawancara.

\section{Waktu Penelitian}

Waktu penelitian dilaksanakan pada bulan September - Februari 2018.

\section{Tempat Penelitian}

Penelitian dilaksanakan di RSU Imelda Pekerja Indonesia Medan khususnya di Bagian Rekam Medis. Lokasi penelitian ditentukan dengan pertimbangan bahwa RSU Imelda Pekerja Indonesia Medan telah melaksanakan pelayanan dasar yang salah satunya adalah pelayanan rekam medis.

\section{Populasi}

Populasi merupakan keseluruhan sumber data yang diperlukan dalam suatu penelitian. Populasi dalam penelitian ini adalah petugas rumah sakit yang berhubungan dengan sistem pelepasan informasi di RSU Imelda Pekerja Indonesia Medan.

\section{Sampel}

Sampel adalah sebagian dari populasi dengan cara tertentu sehingga dianggap bisa mewakili suatu populasi. Dalam penelitian ini adalah 4 orang, dimana 1 orang Direktur rumah sakit Imelda Pekerja Indonesia, 1 orang Kepala Rekam Medis, dan 2 orang petugas penyimpan rumah sakit Imelda pekerja Indonesia.

\section{Teknik Sampling}

Teknik Sampling yang digunakan dalam penelitian ini adalah Non Probability Sampling (tidak acak), dengan menggunakan Quota Sampling yaitu peneliti mengumpulkan subjek yang memenuhi persyaratan ataupun subjek yang mudah ditemui hingga terpenuhinya jumlah yang ditetapkan (Anggraeni, 2010).

\section{Variabel Penelitian}

Variabel adalah hal-hal yang menjadi objek penelitian, yang ditatap dalam suatu kegiatan penelitian (Arikunto, 2010). Variabel dalam penelitian ini adalah:

a. Permintaan informasi rekam medis oleh pihak ke-3:

- Asuransi

- Pendidikan/Penelitian

- Kepolisian/pengadilan

b. Prosedur/aturan tentang pelepasan informasi baik:

- Intern

- Ekstern

c. Penggunaan ijin tertulis pasien/wali

d. Keterlibatan Unit Rekam Medis, petugas rekam medis dan tenaga medis dalam pelepasan informasi medis.

e. Hukum Kerahasiaan Rekam Medis

\section{Definisi Operasional}

Untuk membatasi ruang lingkup atau pengertian variabel-variabel yang diteliti atau diamati, perlu sekali variabel-variabel tersebut diberi batasan atau definisi operasional (Saryono, 2008).

1. Permintaan informasi rekam medis oleh pihak asuransi adalah upaya yang dilakukan oleh pihak asuransi untuk mendapatkan informasi rekam medis dengan tujuan pengklaiman biaya perawatan pasien.

2. Permintaan informasi rekam medis oleh pendidikan/penelitian adalah upaya yang dilakukan oleh institusi pendidikan ataupun penelitian untuk mendapatkan informasi rekam medis dengan tujuan digunakan sebagai referensi pembelajaran.

3. Permintaan informasi rekam medis oleh Kepolisian/Pengadilan adalah upaya yang dilakukan oleh pihak 
Kepolisian/Pengadilan

untuk mendapatkan informasi rekam medis dengan harapan guna memperoleh informasi sebagi bukti otentik di pengadilan.

4. Prosedur/aturan intern tentang pelepasan informasi rekam medis kepada asuransi, Pendidikan/Penelitian dan Kepolisian/Pengadilan adalah peraturan atau aturan yang dikeluarkan oleh pihak rumah sakit dalam hal pengeluaran informasi rekam medis kepada pihak Asuransi, Pendidikan/Penelitian dan Kepolisian/Pengadilan.

5. Penggunaan ijin tertulis pasien/wali adalah pemberian hak atau kewenangan kepada institusi pelayanan kesehatan untuk mengeluarkan atau memberikan informasi medis pasien dengan menandatangani suatu formulir baik dilakukan oleh pasien itu sendiri ataupun dikuasakan kepada wali kepercayaannya.

6. Keterlibatan Sub Bagian Rekam Medis, Petugas Rekam Medis dan Tenaga Medis adalah keikut sertaan atau partisipasi Sub Bagian Rekam Medis, Petugas Rekam Medis dan tenaga medis dalam mengeluarkan informasi dalam menjawab perminataan informasi oleh pihak asuransi, Pendidikan/Penelitian dan Kepolisian/Pengadilan.

7. Hukum Kerahasiaan Rekam Medis adalah peraturan perundang-undangan yang menyatakan bahwa rekam medis memiliki nilai hukum kerahasiaan yang wajib di jaga

\section{Instrumen Penelitian}

Instrumen penelitian adalah alat atau fasilitas yang digunakan oleh peneliti dalam mengumpulkan data agar pekerjaannya lebih mudah dan hasilnya lebih baik (cermat, lengkap dan sistematis) sehingga lebih mudah diolah (Saryono dan Mekar Dwi Anggraini, 2013). Instrumen yang digunakan dalam penelitian ini dengan menggunakan kuesioner.

\section{Cara Pengumpulan Data}

Analisis data yang digunakan adalah analisis univariat yang dilakukan terhadap tiap variabel dari hasil penelitian. Pada umumnya analisis ini hanya menghasilkan distribusi dan persentase dari tiap variabel. Data yang akan dikumpulkan diolah dengan langkah-langkah sebagai berikut:

a. Data primer, yaitu data yang diperoleh dari sumber pertama melalui observasi langsung dilapangan.

b. Data sekunder, data yang diperoleh dari sumber-sumber tertulis dokumen rekam medis, yang berkaitan dengan strategi peningkatan kompetensi petugas rekam medis untuk sumber daya manusia aparatur.

\section{Studi Dukumen}

Metode dokumentasi yaitu mencari data mengenai hal-hal atau variabel yang berupa catatan, transkip, buku, surat kabar, majalah, prasasti, notulen rapat, lengger, agenda, dan sebagainya (Arikunto, 2010).

1. Observasi

Observasi atau pengamatan adalah suatu prosedur berencana, yang antara lain meliputi melihat dan mencatat jumlah dan tariff aktivitas tertentu yang ada hubungannya dengan masalah yang diteliti (Notoatmodjo, 2010). Proses dan syarat pelepasan informasi pasien akan menjadi objek observasi.

2. Wawancara

Wawancara adalah suatu metode yang digunakan untuk mengumpulkan data, di mana penelitian mendapatkan atau perincian secara lisan dari seseorang sasaran peneliti (responden) atau bercakap-cakap secara face to face (Jurnal Normanto, 2011). Menurut Saryono (2010), Wawancara dapat dilakukan secara terstruktur maupun tidak terstruktur, dan dapat dilakukan melalui tatap muka (face to face) maupun dengan menggunakan telepon. Pada penelitian ini wawancara yang dilakukan adalah wawancara terstruktur, dimana peneliti telah menyiapkan instrumen penelitian berupa pertanyaan-pertanyaan tertulis 
sebagai panduan dan wawancara melalui tatap muka.

\section{Pengolahan Data}

Dalam pengolahan data yang telah terkumpulkan, ada beberapa langkah pengolahan data yang terdiri dari:

1. Editing Data

Mengoreksi jawaban yang telah diberikan responden, apabila ada data yang salah atau kurang segera dilengkapi.

2. Coding Data

Melakukan pengkodean terhadap beberapa variabel yang akan diteliti, dengan tujuan untuk mempermudah pada saat melakukan analisis data.

3. Tabulating/Penyajian Data

Suatu penyajian sistematik daripada data numerik, yang tersusun dalam kolom.

\section{Analisis Data}

Setelah pengumpulan data, maka dalam penelitian ini dilakukan analisis data yang digunakan adalah distribusi frekuensi dan juga narasi dari hasil wawancara yang dilakukan.

\section{HASIL}

Tabel 1. Distribusi Frekuensi Responden

\begin{tabular}{|c|c|c|c|c|c|}
\hline \multirow{2}{*}{ No } & \multirow{2}{*}{ Pertanyaaan } & \multicolumn{2}{|c|}{ Ya } & \multicolumn{2}{|c|}{ Tidak } \\
\hline & & $\mathbf{F}$ & $\%$ & $\mathbf{F}$ & $\%$ \\
\hline 1 & $\begin{array}{l}\text { Apakah petugas rekam medis pernah melakukan kesalahan } \\
\text { dalam mengambil keputusan untuk pelepasan informasi? }\end{array}$ & 4 & 100 & 0 & 0 \\
\hline 2 & $\begin{array}{l}\text { Apakah di Rumah Sakit Umum Imelda Pekerja Indonesia } \\
\text { Medan pernah terjadi pelepasan informasi? }\end{array}$ & 3 & 90 & 1 & 10 \\
\hline 3 & $\begin{array}{l}\text { Apakah Rumah Sakit Umum Imelda Pekerja Indonesia } \\
\text { Medan sudah melaksanakan Standar Operasional Prosedur } \\
\text { (SOP) yang sudah ditetapkan? }\end{array}$ & 4 & 100 & 0 & 0 \\
\hline 4 & $\begin{array}{l}\text { Apakah petugas mnjaga kerahasiaan berkas rekam medis di } \\
\text { Rumah Sakit Umum Imelda Pekerja Indonesia Medan? }\end{array}$ & 4 & 100 & 0 & 0 \\
\hline 5 & $\begin{array}{l}\text { Apakah pelepasan informasi berkas rekam medis di Rumah } \\
\text { Sakit Umum Imelda Pekerja Indonesia Medan sudah sesuai } \\
\text { dengan peraturan yang di tetapkan? }\end{array}$ & 4 & 100 & 0 & 0 \\
\hline 6 & $\begin{array}{l}\text { Apakah boleh petugas melakukan pelepasan informasi } \\
\text { kepada pihak pengadilan? }\end{array}$ & 4 & 100 & 0 & 0 \\
\hline 7 & $\begin{array}{l}\text { Apakah penyimpanan berkas rekam medis Rumah Sakit } \\
\text { Umum Imelda Pekerja Indonesia Medan sudah menjamin } \\
\text { karahasiaan pasien? }\end{array}$ & 4 & 100 & 0 & 0 \\
\hline 8 & $\begin{array}{l}\text { Apakah petugas rekam medis mempunyai langkah-langkah } \\
\text { dalam melakukan pelepasan informasi berkas rekam medis ? }\end{array}$ & 4 & 100 & 0 & 0 \\
\hline 9 & $\begin{array}{l}\text { Apakah petugs rekam medis mempunyai langkah-langkah } \\
\text { didalam menjaga kerahasiaan berkas rekam medis? }\end{array}$ & 4 & 100 & 0 & 0 \\
\hline 10 & $\begin{array}{l}\text { Apakah persetujuan pelepasan informasi diperlukan tanda } \\
\text { tangan dari pasien? }\end{array}$ & 4 & 100 & 0 & 0 \\
\hline 11 & $\begin{array}{l}\text { Apakah petugas melakukan pencatatan setiap peminjaman } \\
\text { berkas rekam medis? }\end{array}$ & 4 & 100 & 0 & 0 \\
\hline 12 & $\begin{array}{l}\text { Petugas seharusnya sering mendapatkan pelatihan agar } \\
\text { prestasi kerja dapat meningkat? }\end{array}$ & 4 & 100 & 0 & 0 \\
\hline 13 & $\begin{array}{l}\text { Pendidikan yang berkelanjutan dapat meningkatkan keahlian } \\
\text { dan pengetahuan? }\end{array}$ & 4 & 100 & 0 & 0 \\
\hline 14 & $\begin{array}{l}\text { Apakah petugas bebas melakukan pelepasan informasi } \\
\text { kepada yang pihak lain yang memintak berkas rekam medis ? }\end{array}$ & 0 & 0 & 4 & 100 \\
\hline 15 & $\begin{array}{l}\text { Apakah pihak asuransi perlu memintak ijin tertulis dari } \\
\text { pasien untuk mengeluarkan informasi medis? }\end{array}$ & 4 & 100 & 0 & 0 \\
\hline
\end{tabular}

Sumber: Data yang diolah dari wawancara 
Berdasarkan tabel 1 dapat diketahui bahwa pelepasan informasi rekam medis di RSU Imelda Pekerja Indonesia Medan sudah optimal dan sesuai dengan SOP RSU Imelda Pekerja Indonesia Medan.

\section{PEMBAHASAN}

\section{Prosedur Pelepasan Informasi Rekam Medis}

Pada dasarnya alur prosedur pelepasan informasi medis kepada pihak ketiga di RSU Imelda Pekerja Indonesia medan sudah optimal karena sudah mempertimbangkan aspek kerahasiaan informasi medis yang terdapat dalam rekam medis pasien yang merupakan rahasia kedokteran dan wajib dijaga kerahasiaannya yang sudah ditetapkan oleh menteri kesehatan seperti yang tercantum dalam peraturan pemerintah No. 10 Tahun 1966 tentang wajib simpan rahasia kedokteran. Dari hasil observasi dan wawancara mendalam yang telah dilakukan oleh peneliti di RSU Imelda Pekerja Indonesia Medan, diperoleh ada 7 macam alur prosedur pelepasan informasi medis pasien kepada pihak ke-3 yaitu:

\section{Prosedur Pelepasan Informasi Kepada Pihak Asuransi}

Gambar 1. Prosedur Pelepasan Informasi Untuk Klaim Asuransi Yang Berkerjasama Dengan Pihak Rumah Sakit

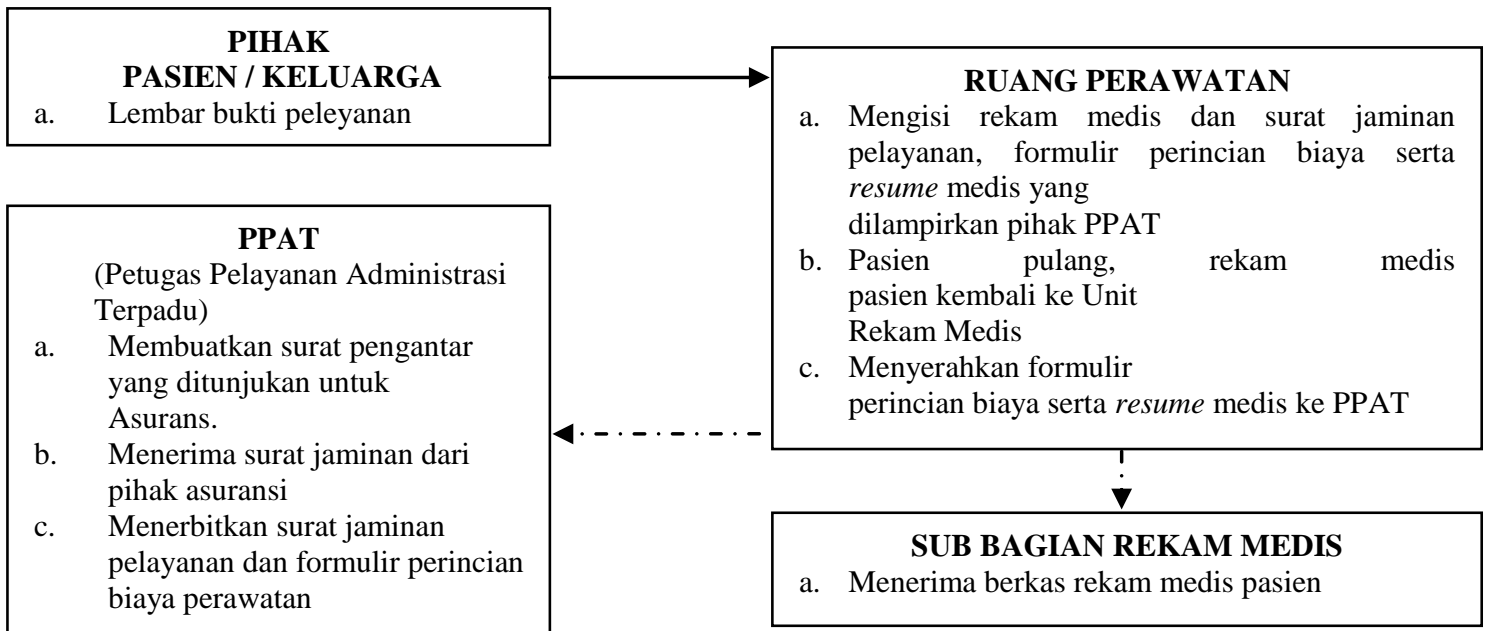

\section{a. Peyelesaian proses pennggantian} biaya perawatan tertanggung

Sumber: Data yang diolah dari wawancara

Keterangan:

Proses yang dilalui:

Proses pilihan:-......

Prosedur diatas menunjukkan bahwa pihak pasien harus membawa lembar bukti pelayanan dari IGD atupun poliklinik yang menunjukkan bahwa pasien perlu dirawat inap kepada petugas pelayanan administrasi terpadu (PPAT), petugas PPAT selanjutnya membuatkan surat pengantar pengajuan klim kepada PT asuransi dimana pasien menjadi anggota PT asuransi tersebut, PT asuransi mengeluarkan surat jaminan bahwa pasien adalah anggota dari asuransi tersebut.

Melalui pasien atau keluarga pasien, surat jaminan yang dikeluarkan pihak asuransi di serahkan kepada PPAT untuk di arsipkan. Kemudian PPAT menerbitkan surat jaminan pelayanan, resume medis serta perinciaan biaya perawatan dimana pasien diberikan perawatan. Didalam ruang perawatan, petugas medis mengisi rekam 
medis dan surat jaminan pelayanan, formulir perincian biaya serta resume medis yang dilampirkan pihak PPAT. Setelah pasien pulang, berkas rekam medis pasien kembali ke Unit bagian Rekam Medis untuk disimpan dirak penyimpanan. Namun formulir rincian biaya perawatan dan resume medis diserahkan kembali ke pihak PPAT.

Dari hasil wawancara dengan petugas PPAT bahwa dalam pengeluaran informasi medis pasien kepada pihak asuransi memang belum ada penggunaan ijin tertulis dari pasien. Ini dikarenakan bahwa setiap pasien mendaftar dengan cara pembayaran menggunakan asuransi dan telah menyerahkan kepercayaan kepada pihak PPAT dalam hal informasi medis dan pembayaran biaya perawatan yang diberikan.

Dalam klaim biaya pelayanan, pihak PPAT RSU Imelda Pekerja Indonesia Medan harus melengkapi persyaratan yaitu:

a. Surat jaminan asli yang dibuat oleh pihak asuransi.

b. Surat jaminan pelayanan dari rumah sakit.

c. Fotocopy kartu peserta asuransi

d. Rincian biaya perawatan.

e. Resume medis pasien.

2. Prosedur Pelepasan Informasi Kepada Pihak Pendidikan atau Peneliti

Gambar 2. Prosedur Pelepasan Informasi untuk penelitian

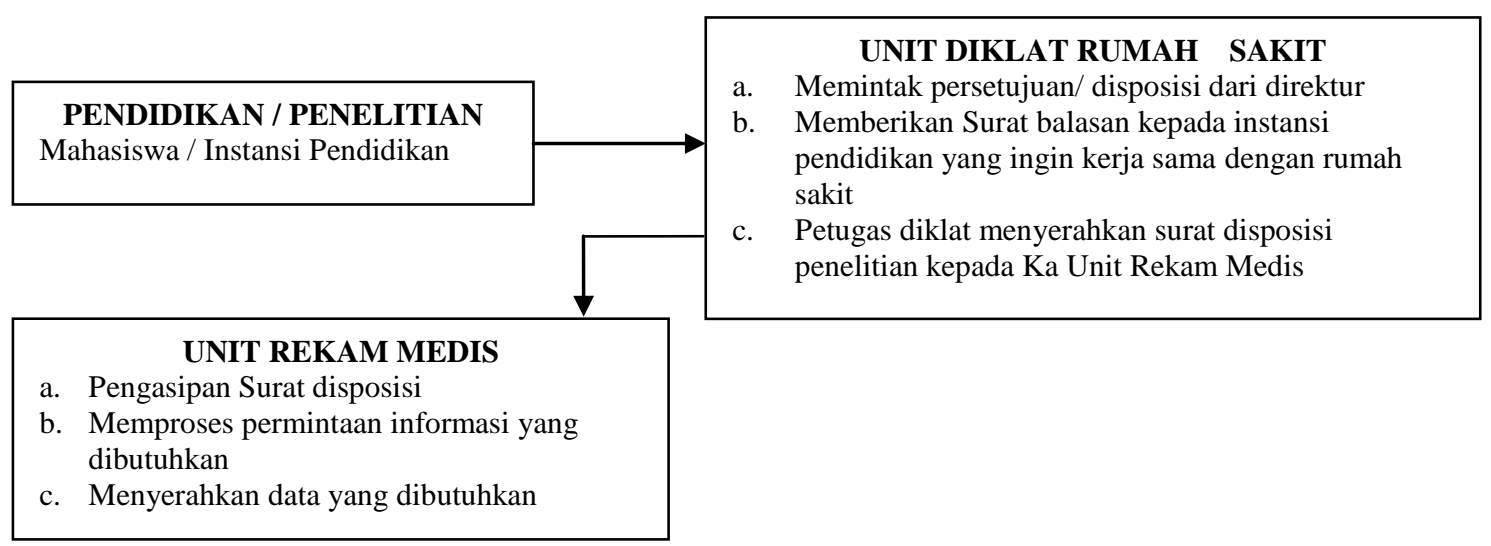

Sumber: Data yang diolah dari wawancara

Prosedur permintaan Informasi guna penelitian Unit Bagian Rekam Medis di RSU Imelda Pekerja Indonesia Medan, dimana Institusi pendidikan yang berkepentingan harus membawa surat permintaan kerjasama dengan Rumah Sakit, selanjutnya pihak Diklat Rumah Sakit memproses permintaan tersebut dengan meminta disposisi dari Direktur Rumah Sakit.

Setelah disetujui, pihak Diklat mengirimkan surat balasan kepada Instansi pendidikan untuk dapat melakukan penelitian di Rumah Sakit. Selanjutnya pihak diklat menyerahkan surat disposisi kepada Asisten Manajer Rekam Medis. Penelitian dapat dilakukan dengan persyaratan dalam membuka informasi
Rekam Medis, peneliti harus tetap berada di dalam ruangan tanpa boleh membawa ke luar dari ruangan Unit Kerja Rekam Medis.

3. Prosedur Pelepasan Informasi Kepada Pihak Pengadilan atau kepolisian.

Prosedur pelepasan informasi kepada pihak ketiga dalam lingkup pengadilan terdiri dari pelepasan informasi guna klaim Jasa Raharja dan permintaan visum Et Repertum. Untuk prosedur pelepasan informasi guna klaim jasa Raharja dan permintaan Visum Et Repertum, hampit sama dengan proses pelepasan informasi guna klaim Asuransi dan permintaan resume medis, hanya saja untuk permintaan Visum Et Repertum, diharuskan ada surat resmi dari pihak pemohonan yaitu penyidik atau 
polisi yang diberi tanggung jawab langsung dari pihak pemohonan

Pada wawancara yang telah dilakukan diketahui bahwa dalam pelepasan informasi rekam medis untuk keperluan Visum Et Repertum dan bukti pengadilan, pihak pemohon yaitu penyidik harus meminta ijin tertulis dari pasien, namun tetap harus menunjukkan surat resmi dari kepolisian maupun dari pengadilan yang ditunjukan kepada direktur rumah sakit. Pasien yang akan di Visum Et Repertum di RSU Imelda Pekerja Indonesia Medan, seperti kasus pemerkosaan atau pelecehan seksual, kasus penganiayaan/criminal, kasus kecelakaan, kasus keracunan, penganiayaan anak atau kekerasan dalam rumah tangga (KDRT) dan kasus-kasus umum lainnya yang bersangkutan dengan hukum.

4. Pihak yang terlibat dalam proses permintaan informasi rekam medis pasien rawat inap kepada pihak ke-3.

Adapun orang ataupun pihak yang terlibat dalam proses pelepasan informasi medis pasien di RSU Imelda Pekerja Indonesia Medan adalah:

Tabel 2. Pihak yang Terlibat Pelepasan Informasi Medis

\begin{tabular}{llll}
\hline No & Pihak Yang Terlibat & & \\
\hline 1 & Diklat & & \\
\hline 2 & $\begin{array}{l}\text { Kepala Rekam Medis dan } \\
\text { Rekam medis }\end{array}$ & \\
\hline 3 & Dokter dan Tenaga Medis & \\
\hline
\end{tabular}

Kepala Rekam Medis atau Bagian Rekam Medis adalah unit yang memfasilitasi pelepasan informasi medis pasien dalam hal klaim Asuransi, permintaan data pendidikan atau penelitian, dan permintaan keterangan medis dan pelepasan informasi guna kepolisian dan pengadilan. Dokter dan tenaga kesehatan adalah petugas yang berhak membuka informasi rekam medis pasien dalam permintaan klaim asuransi, surat keterangan medis dan permintaa kepolisian dan pengadilan.

Diklat adalah bagian dari rumah sakit yang memfasilitasi kepangurusan persetujuan pendidikan dan penelitian didalam RSU Imelda Pekerja Indonesia
Medan. Namun semua pelepasan informasi rekam medis haruslah sepengetahuan dari pimpinan seranan peleyanan kesehatan, sesuai dengan PerMenKes Ri No. 269/MENKES/PER/III/2008 BAB V Pasal 14 yang menyebutkan bahwa "pimpinan serana peleyanan kesehatan bertanggung jawab atas hilang, rusak, pemalsuan dan penggunaan oleh orang atau badan yang tidak berhak terhadap rekam medis".

5. Penggunaan Ijin Tertulis Pasien Dalam Proses Pengeluaran Informasi Medis Kepada Pihak Ke-3.

Laporan atau catatan yang terdapat dalam rekam medis adalah sebagai hasil pemeriksaan, pengobatan, observasi ataupun wawancara dengan pasien. Informasi yang tidak boleh disebarluaskan kepada pihak yang tidak berwenang, karena menyangkut informasi medis individu pasien secara langsung.

Oleh karena itu diperlukan ijin tertulis dari pasien pada setiap pengeluaran informasi medis yang ada. Sedangkan menurut hasil observasi dan wawancara di Sub Bagian Rekam Medis di RSU Imelda Pekerja Indonesia Medan telah memiliki formulir tentang perijinan tertulis dari pasien.

6. Keterlibatan Sub Bagian Rekam Medis Rekam medis memiki tanggung jawab dalam menyimpan informasi megenai pasien serta keterlibatan dalam pelepasan informasi yang harus dilaksanakan sesuai dengan SOP atau peraturan yang sudah ditetapkan.

7. Prosedur yang dilakukan RSU Imelda Pekerja Indonesia Medan Dalam Menjamin Aspek Hukum Kerahasiaan Pasien

Dalam menjamin aspek kerahasian informasi medis pasien, RSU Imelda Pekerja Indonesia Medan Khususnya pada Sub Bagian Rekam Medis, telah memiliki prosedur tetap tentang penggunaan informasi rekam medis, peminjaman rekam medis dan prosedur pengurusan surat keterangan dokter untuk jamsostek, Jasa Raharja, Asuransi dan informasi medis. 
Isi dari prosedur tetap penggunaan informasi rekam medis di RSU Imelda Pekerja Indonesia Medan adalah:

a. Pengertian: Sebagai acuan dengan lengkap pelaksanaan penggunaan informasi rekam medis

b. Tujuan: Memberikan informasi rekam medis pasien

c. Kebijakan: Penggunaan informasi rekam medis adalah milik Rumah Sakit, sedangkan isi dari rekam medis adalah milik pasien dan dijaga kerahasiaannya.

d. Prosedur:

1. Pada dasarnya rekam medis tidak boleh dibawa keluar dari rumah sakit. Untuk pasien yang dirujuk ke rumah sakit lain harus menjaga kerahasiaan pasien sedangkan resumenya dibuat oleh dokter.

2. Untuk kepentingan riset penelitian dokter dapat meminjam rekam medis setelah ada ijin tertulis dari direktur. Dalam hal penelitian hanya boleh dikeluarkan di ruang rekam medis.

3. Demi tertibnya pelayanan RSU Imelda Pekerja Indonesia Medan untuk keperluan risetrt peminjaman ke urusan rekam medis setelah ada ijin dari direktur.

4. Petugas rekam medis mencatat berkas rekam medis yang akan dipinjam dan ditandatangani oleh peminjam.

\section{KESIMPULAN}

Dari hasil penelitian dapat disimpulkan bahwa sistem pelepasan informasi RSU Imelda Pekerja Indonesia Medan sudah optimal dan sudah melaksanakan SOP yang telah ada di RSU Imelda Pekerja Indonesia Medan.

\section{SARAN}

1. Bagi Instansi Rumah Sakit

Bagi instansi rumah sakit agar dalam menjaga kerahasian dan keamanan informasi pasien di RSU Imelda Pekerja Indonesia Medan, sebaiknya untuk pencatatan peminjaman atau untuk melakukan pelepasan informasi untuk pihak ke-3 dalam mendokumentasikan sebaiknya Rumah Sakit Imelda Medan menggunakan pendokumentasian terkomputerisasi agar lebih aman dan mudah untuk perhitungan data, pendokumentasian bertujuan sebagai bentuk bukti apabila terjadi tuntutan kelak.

2. Bagi Institusi Pendidikan

Diharapkan bagi institusi pendidikan akademi perekam informasi kesehatan imelda medan untuk lebih memperbanyak referensi buku mengenai rekam medis dan agar memperbanyak waktu dalam praktek kerja lapangan serta pembagian waktu.

3. Bagi Peneliti Selanjutnya

Bagi penelitian selanjutnya hendaknya melakukan penelitian yang lebih cermat sehingga hasil penelitian lebih bagus dari yang sebelumnya.

\section{DAFTAR PUSTAKA}

Aditama YT. (2006). Manajemen Administrasi Rumah Sakit. Edisi ke-2. Jakarta:UI-Press.

Arikunto S. (2010). Prosedur Penelitian Suatu Pendekatan Praktik. Jakarta: Rineka Cipta.

Budi S. (2011). Manajemen Unit Kerja Rekam Medis. Yogyakarta: Quantum Sinergis Media.

Firdaus SU. (2008). Rekam Medis dalam Sorotan Hukum dan Etika. Surakarta: LPP UNS dan UNS Press.

Hatta GR. (2008). Pedoman Manajemen Informasi Kesehatan di Sarana Pelayanan Kesehatan. Jakarta: UI Press.

http://eprints.undip.ac.id/17431/ETI_MURD ANI.pdf [Accessed 04 Juni 2011].

http://www.wma.net/en/30publications/30et hicsmanual/pdf/ethics manual indones ia.pdf [Accessed 4 Juni 2018]

Huffman, Edna K, RRA. (1994). Health Information Managemant, Tenth Edition. Berweyn: Illinois Physicians'Record Company. http://www.wma.net/en/30publications/ 
30ethicsmanual/pdf/ethics_manual_ind onesia.pdf. [accessed 14 Mei 2018]

M Thalal dan Hiswani. Aspek Hukum Dalam Pelayanan Kesehatan. Administrasi Fakultas Tehnik USU. Departemen Epidemiologi Fakultas Kesehatan Masyarakat USU. Diakses: 25 Mei 2018.

http://repository.usu.ac.id/bitstream/123 456789/19039/1/ikm-jin2.pdf.

Menteri Kesehatan Republik Indonesia. (200 8). Peraturan Nomor: 269/MENKES/P ER/III/2008.tentang Rekam Medis. Jakarta: Departemen Kesehatan RI.

Muninjaya GAA. (2016). Manajemen Kesehatan Edisi Ke-3. Jakarta: EGC.

Murdani E. (2007). Pengembangan Sistem Informasi Rekam Medis Rawat Jalan Untuk Mendukung Evaluasi Pelayanan di RSU Bina Kasih Ambarawa. Tesis. Ilmu Kesehatan Masyarakat. Universitas Diponogoro Semarang.

Normanto E. (2011). Tinjauan Pelepasan Informasi Rekam Medis dalam Menjamin Aspek Hukum Kerahasian Rekam Medis di RSUD Dr. H.Moch. Ansari Saleh. Kti Stikes Husada Borneo. Banjarmasin.

Notoatmodjo S. (2004). Undangundang RI No.29 Tahun 2004 tentang Praktik Kedokteran. Jakarta.

Notoatmodjo S. (2010). Metodologi Penelitian Kesehatan. Jakarta: Rineka Cipta.

Presiden Republik Indonesia. (1966). Undan g-undang RI No. 4 Tahun 1984 tentang Wabah Penyakit Manular. Jakarta.
Rosari L. (2011). Perlindungan Hukum terhadap Pasien Sebagai Konsumen Jasa di Bidang Pelayanan Medis Berdasarkan Kitab Undang-Undang Hukum Perdata. KTI. Stikes Husada Borneo. Banjarmasin.

Rustiyanto E. (2009). Etika Profesi Perekam Medis dan Informasi Kesehatan. Edisi ke-1. Yogyakarta: Graha Ilmu.

Sagiran (ed). (2006). Panduan Etika Medis. Yogyakarta: Pusat Studi Kedokteran Islam Fakulitas Kedokteran Universitas Muhammadiyah Yogyakarta Indonesia.

Saryono dan Anggreni M. (2013). Metodologi Penelitian Kualitatif dan Kuantitatif dalam Bidang Kesehatan. Yogyakarta: Nuhu Medika.

Saryono. (2008). Metodologi Penelitian Kesehatan. Yogyakarta: Mitra Cindekia.

Saryono. (2010). Metodologi Penelitian Kesehatan. Yogyakarta: Mitra Cindekia.

Sjamsuhidajat dan Sabir A. (2006). Manual Rekam Medis. Konsil Kedokteran Indonesia.

Soeparto P. (2006). Etika dan Hukum di Bidang Kesehatan. Jakarta: Airlangga University press.

World Health Organization. (2000). Pengertian Rumah Sakit. Jakarta: WHO.

World Health Organization. (2006). Medical Records Manual A Guide for Developing Countries. Geneva: WHO. 